\title{
Cultivar Preference and Genotype Distribution of the Brown Stem Rot Pathogen Phialophora gregata in the Midwestern United States
}

D. K. Malvick, Department of Crop Sciences, University of Illinois at Urbana-Champaign, Urbana 61801; W. Chen, United States Department of Agriculture-Agricultural Research Service, Washington State University, Pullman 99164; J. E. Kurle, Department of Plant Pathology, University of Minnesota, St. Paul 55108; and C. R. Grau, Department of Plant Pathology, University of Wisconsin-Madison, Madison 53706

\begin{abstract}
Malvick, D. K., Chen, W., Kurle, J. E., and Grau, C. R. 2003. Cultivar preference and genotype distribution of the brown stem rot pathogen Phialophora gregata in the midwestern United States. Plant Dis. 87:1250-1254.

Brown stem rot (BSR), caused by Phialophora gregata f. sp. sojae, is an important yield-limiting disease of soybean (Glycine max) in the midwestern United States. Midwestern populations of $P$. gregata are separated into genotypes A and B based on intergenic spacer sequences of nuclear ribosomal DNA. Genotype A causes both leaf and stem symptoms, and genotype B typically causes internal stem symptoms only. Data are limited on the geographic distribution of genotypes A and B. It is not well understood whether cultivars may be infected preferentially by a genotype. Field plots were established at five sites in Illinois, three sites in Wisconsin, and two sites in Minnesota in two different years. Soybean cvs. Bell, BSR101, Dwight, Sturdy, Williams 82, LN92-12033, and LN92-12054 were sown with two to four replications at each field site. From each plot, 5 to 10 stems were harvested arbitrarily at the R8 growth stage and assayed by polymerase chain reaction to detect the A and B genotypes. Both pathogen genotypes were detected at all locations except Urbana, where only genotype A was detected, and St. Paul, where only B was detected. Genotype A was the predominant genotype detected in susceptible cvs. Williams 82 and LN92-12054, with 70 and 78\% of infected stems, respectively, positive for A. The other susceptible cultivar, Sturdy, yielded predominantly genotype A at four of the seven Illinois and Wisconsin locations where both pathogen genotypes were present, but yielded predominantly B at the Minnesota location where both genotypes were detected. Genotype B was the predominant type detected in partially resistant cvs. Dwight, LN92-12033, and Bell, with 56,85 , and $99 \%$ of the infected stems, respectively, testing positive for B.
\end{abstract}

Brown stem rot (BSR) of soybean (Glycine $\max$ L.) caused by the imperfect, soilborne fungus Phialophora gregata $\mathrm{f}$. sp. sojae (Allington \& D. W. Chamberlain) W. Gams, occurs in the midwestern and southeastern United States $(13,35)$. This

Corresponding author: D. K. Malvick

E-mail: dmalvick@uiuc.edu

This research was partially funded by the Illinois Council on Food and Agricultural Research (CFAR), the University of Illinois at UrbanaChampaign Hatch project ILLU-15-0367, USDA/CREES North Central IPM Program, the University of Minnesota Hatch project number 2226, the Minnesota Soybean Research and Promotion Council, and the University of WisconsinMadison, College of Agriculture and Life Sciences, Hatch project number 4244. Any opinions, findings, and conclusions expressed in this article are those of the authors and do not necessarily reflect the views of the supporting agencies. Names are necessary to report factually on available data; however, the USDA neither guarantees nor warrants the standard of the product, and the use of the names by the USDA implies no approval of the product to the exclusion of others that may also be suitable.

Accepted for publication 22 May 2003.

Publication no. D-2003-0804-01R

(C) 2003 The American Phytopathological Society disease is especially important in the northcentral United States. Typical symptoms associated with BSR are dark brown discoloration of the pith in the lower stems and internodes, interveinal yellowing and necrosis on leaves, and defoliation $(2,13,25)$. The expression of foliar symptoms is inconsistent and is influenced by air temperature, rainfall, soil edaphic factors, pathogen isolate, tillage systems, and soybean cultivar $(3,12,20,26,27,29,31,33,34)$.

The effect of BSR on soybean yields is unclear. Several researchers have reported yield losses up to $34 \%$ when foliar symptoms were present and $8 \%$ when foliar symptoms were absent $(2,25,30)$; however, Whiting and Crookston (32) were unable to detect reduced yields when BSR stem symptoms were present. BSR is managed via crop rotation and host resistance (1$5,13,21)$.

Although various factors govern yield loss caused by BSR, the importance of pathogenic variation in populations of $P$. gregata is becoming clear. Isolates of $P$. gregata vary by pathotype, colony traits, genotype, and type of symptoms associated with infection of specific soybean germ plasm $(6,12,24,28,33)$. Two different pathogenic types of $P$. gregata have been reported: defoliating (type I) isolates that cause vascular browning in stems, as well as leaf chlorosis, necrosis, and defoliation; and nondefoliating (type II) isolates that cause vascular browning and occasional minor foliar symptoms, but do not cause defoliation $(6,12,19)$.

The phenotypic variation for pathogenicity among isolates of $P$. gregata has been reported often; however, recently, a genetic marker has been developed to identify the type I and II pathogenic types (6). Speciesspecific polymerase chain reaction (PCR) primers can distinguish between the two types based on variation in the intergenic spacer region of the nuclear ribosomal DNA (6). The two genotypes distinguished by PCR have been termed genotype A and $\mathrm{B}$, which correspond to pathotypes I and II, respectively. Genotype-specific primers have enabled researchers to determine that both genotypes occur in several Midwestern states (6); however, the distribution of the A and B genotypes within major soybean production areas is poorly understood and improved methods are needed to conduct surveys.

In addition to the pathogenic and genotypic differences among isolates of $P$. gregata, preliminary data also suggests that the different genotypes may preferentially infect certain soybean cultivars based on the presence or absence of $R b s$ genes. An apparent soybean cultivar preference for genotypes A and B of P. gregata was reported from nonreplicated plots at one location in Wisconsin (6). Based on this preliminary study, we wished to evaluate cultivar preference of $P$. gregata genotypes in replicated plots at multiple locations representing different climates, soil types, and geographic locations.

The main objective of this study was to determine the extent and specificity of soybean cultivar preference for $P$. gregata genotypes A and B in Illinois, Wisconsin, and Minnesota. Secondary objectives were to (i) determine the distribution of the two genotypes over multiple locations and (ii) determine which soybean cultivars are effective baiting hosts for surveying the distribution of the genotypes A and $\mathrm{B}$ of $P$. gregata. A preliminary report of this work has been published (23).

\section{MATERIALS AND METHODS}

Field plots were established with various soybean cultivars and experimental lines at 
nine field locations in Illinois, Minnesota, and Wisconsin in May 1999 and 2001 to determine frequency of infection by $P$. gregata genotypes $\mathrm{A}$ and $\mathrm{B}$. Four of the cultivars are partially resistant to BSR: Bell, BSR 101 (Rbs1 and Rbs3), Dwight, and LN92-12033 (Rbs2); and three cultivars are susceptible: Sturdy, Williams 82, and LN92-12054. Bell and Dwight express resistance to BSR in the field $(18,22)$. Only Bell and Dwight have a known source of resistance (PI88788) to soybean cyst nematode. Four plots in Illinois were located near the cities of DeKalb (Catlin silt loam [SL]), Goodfield (Ipava SL), Monmouth (Muscatine SL), and Urbana (Flanigan SL). The DeKalb plots were in different field locations each year. The two Minnesota plots (Waukegan SL) were near the cities of Rosemount and St. Paul. The three plots in Wisconsin were near Arlington, Janesville (both Plano SL), and Hancock (Plainfield sand).

The cultivars were replicated two to four times in a randomized complete block design at each location. All field locations had a corn-soybean rotation history. Plots consisted of four rows $6.4 \mathrm{~m}$ long planted in a $0.75-\mathrm{m}$ row spacing at a seeding rate of $125 \mathrm{seed} / \mathrm{m}$. Plots were subjected to natural rainfall throughout the growing season with no supplemental irrigation, and standard agronomic management practices were used at all locations.

In all, 5 or 10 mature stems were harvested arbitrarily from each plot at the R8 growth stage. Plants were cut off at the soil level and stored at $23^{\circ} \mathrm{C}$. Total genomic DNA was extracted from soybean stem fragments from the lower 8 to $12 \mathrm{~cm}$ of the stems using a FastDNA extraction system (Qbiogene/Bio101, Carlsbad, CA) as described previously (8). Isolation of $P$. gregata was not attempted from the plants tested in this study.

The DNA extracted from the stems was used in PCR tests with primers specific for genotypes of $P$. gregata (6). The primer pair BSRIGS1 and BSRIGS2 was used to amplify different-sized PCR products specific for genotypes A (1,020 bp) and B (830 bp) to determine which genotypes were present in the stem samples (6). Amplified DNA fragments were detected in a $1 \%$ agarose gel stained with ethidium bromide. PCR amplifications were repeated twice for all plants tested from the 2001 Monmouth, IL and Janesville, WI locations. The number and percentage of plants of each cultivar from all locations that tested positive for each genotype of $P$. gregata were determined. The null hypothesis that the soybean cultivars were infected at the same frequency by the two genotypes was tested with $\chi^{2}$ analysis.

\section{RESULTS}

$P$. gregata was detected with a specific PCR test in soybean plants grown at all locations in 2001 and 1999. This pathogen was detected in $31 \%$ of the plants assayed in 2001 and $46 \%$ of the plants assayed in 1999. Both genotypes A and B of P. gregata were detected at seven of the nine experimental sites (Table 1). Either genotype A or B was detected in most single infected plants; only two 'Sturdy' plants grown at the Janesville, WI location yielded PCR products of both the A and B genotypes. A previous study showed that the presence of PCR products of the A and $\mathrm{B}$ genotypes in individual plants was due to dual infection by the A and $\mathrm{B}$ genotypes and not due to the presence of a third genotype (10). Foliar symptoms of BSR were observed in 5 to $10 \%$ of plants at DeKalb, Monmouth, Arlington, and Janesville in 2001. Foliar symptoms were not observed at the other locations in 2001, and were not recorded in 1999.

Either genotype A or B of $P$. gregata was detected predominantly $(P<0.05$ to 0.2 ) in all of the seven different soybean cultivars in at least one location (Tables 1 and 2). Genotype A was detected at a higher frequency than genotype B in two of the three BSR-susceptible cultivars (Williams 82 and LN92-12054) and one resistant cultivar (BSR101), and A and B were detected overall at similar frequencies in BSR-resistant Dwight and BSRsusceptible Sturdy, although the relative frequencies of detection for each genotype varied by location. When data were combined from both years and all locations where both genotypes were confirmed, genotype A was detected in 77,73 , and $69 \%$ of infected stems of cvs. LN9212054, BSR101, and Williams 82, respectively (Table 2). Genotype B was detected at higher levels than A in resistant cvs. Bell and LN92-12033, with 99 and $85 \%$ of infected stems, respectively, positive for B (Table 2). The relatively higher frequency of detection of genotype B in BSR-resistant germ plasm is shown clearly in the comparison between Bell and Williams 82 and, moreover, between LN92-12033 and LN92-12054, which are two isogenic lines (28) that differ by the presence or absence of Rbs2 (Tables 1 and 2). The frequency of detection of A versus B varied by location (Table 1).

Relative infection frequency by either of the two genotypes was inconsistent and varied by location (Table 1). For example, genotype A was the predominant genotype detected overall in Williams 82, but genotype $\mathrm{B}$ was detected in this line at a higher rate than $\mathrm{A}$ at the Arlington location (Tables 1 and 2). Although the total combined results suggest that Sturdy has no clear preference for either genotype, at several locations A was detected more frequently than B in Sturdy, and at other locations B was detected more frequently. Genotype A was the predominant genotype detected in Sturdy at the DeKalb location in 1999 (73\% A) and 2000 (100\% A), and at the Hancock 1999 location (100\% A), but B was the predominant genotype detected in Sturdy from the Rosemount $(84 \% \quad$ B $)$ location.

The number of plants in which $P$. gregata was detected with the PCR test and the frequency of A and B detection differed among the field locations in 1999 and 2001 (Table 1). Only genotype A was detected in plants from the Urbana location, and only genotype B was detected at the St. Paul location. Both genotypes were detected in varying frequencies at all other locations (Table 1).

\section{DISCUSSION}

The two pathotypes of $P$. gregata were first described by Gray (12), and additional characterization was completed in other studies $(19,24,33)$. Our understanding of the distribution and importance of pathotypes I and II has increased considerably; and advances have been made in understanding population genetic structure of the two pathotypes, molecular genetic characteristics that distinguish the two pathogenic types, and pathogenicity $(2,6,9,11,14-17,19,25,36)$. Much remains unknown, however, concerning the distribution, importance, and pathogenicity of the two pathotypes, which are now known to be genotypically distinct and are termed genotypes A and B based on specific PCR tests.

Three key results from this study contribute to the understanding of the two genotypes of $P$. gregata. First, several soybean germ plasms were infected differentially by genotypes A and B, suggesting a host preference for the $P$. gregata genotypes. Second, by using uniform cultivars and plots at nine locations in three states, the percentage of plants in which $P$. gregata was detected and relative frequencies of A versus B detection was found to differ among the locations. This indicates that the population composition or activity of $P$. gregata varied among the geographic locations. Finally, soybean germ plasm was identified that can be used to semiselectively bait genotypes A and B from field plots.

The results suggest that there is some degree of host genotype specialization or differential competitive ability in $P$. gregata that governs the pathogen genotypehost interaction. Either genotype A or B of $P$. gregata was detected in significantly greater relative abundance in most of the soybean germ plasms used in this study. Although this indicates that there is cultivar preference, there is insufficient evidence of specific interactions between genotypes and cultivars to suggest that races of $P$. gregata f. sp. sojae have developed. Regardless, the data show that host germ plasm does, in some way, influence differential infectivity of the two pathogen genotypes. Cultivars susceptible to BSR appeared to be predominantly infected by genotype A, while two of three resistant 
Table 1. Number of soybean stems tested from seven different soybean cultivars at 10 different year-locations and number of stems that tested positive for genotypes A and B of Phialophora gregata with a polymerase chain reaction test by location and cultivar

\begin{tabular}{|c|c|c|c|c|c|c|}
\hline \multirow[b]{2}{*}{ Location, cultivar } & \multirow[b]{2}{*}{ Year tested } & \multicolumn{3}{|c|}{ Number of stems } & \multirow[b]{2}{*}{$\chi^{2}$ value } & \multirow[b]{2}{*}{ A:B ratio } \\
\hline & & Total tested & Positive for genotype A & Positive for genotype B & & \\
\hline \multicolumn{7}{|l|}{ Arlington, WI } \\
\hline Bell & 2001 & 20 & 1 & 16 & $13.2^{\mathrm{a}}$ & $\ldots$ \\
\hline Dwight & 2001 & 20 & 1 & 1 & $0.0^{\mathrm{b}}$ & $\cdots$ \\
\hline Sturdy & 2001 & 20 & 8 & 6 & $0.3^{\mathrm{b}}$ & $\cdots$ \\
\hline Williams 82 & 2001 & 20 & 1 & 8 & $5.4^{\mathrm{a}}$ & $\ldots$ \\
\hline LN92-12033 & 2001 & 20 & 0 & 9 & $9.0^{\mathrm{a}}$ & $\ldots$ \\
\hline Location total & $\ldots$ & 100 & 11 & 40 & $\ldots$ & $1: 3.6$ \\
\hline \multicolumn{7}{|l|}{ DeKalb, IL } \\
\hline \multirow[t]{2}{*}{ Bell } & 2001 & 20 & 0 & 2 & $2.0^{\mathrm{c}}$ & $\ldots$ \\
\hline & 1999 & 20 & 0 & 12 & $12.0^{\mathrm{a}}$ & $\ldots$ \\
\hline BSR-101 & 1999 & 20 & 4 & 5 & $0.1^{\mathrm{b}}$ & $\cdots$ \\
\hline \multirow[t]{2}{*}{ Dwight } & 2001 & 20 & 1 & 0 & $1.0^{\mathrm{b}}$ & $\ldots$ \\
\hline & 1999 & 20 & 0 & 5 & $5.0^{\mathrm{a}}$ & $\ldots$ \\
\hline \multirow[t]{2}{*}{ Sturdy } & 2001 & 20 & 6 & 0 & $6.0^{\mathrm{a}}$ & $\begin{array}{l}\cdots \\
\cdots\end{array}$ \\
\hline & 1999 & 20 & 8 & 3 & $2.3^{\mathrm{c}}$ & $\ldots$ \\
\hline Williams 82 & 2001 & 20 & 6 & 0 & $6.0^{\mathrm{a}}$ & $\ldots$ \\
\hline LN92-12033 & 2001 & 20 & 1 & 0 & $1.0^{\mathrm{b}}$ & $\ldots$ \\
\hline LN92-12054 & 2001 & 20 & 3 & 0 & $3.0^{\mathrm{d}}$ & \\
\hline Location total & $\ldots$ & 200 & 29 & 37 & $\ldots$ & $1: 1.3$ \\
\hline Goodfield, IL & & & & & & \\
\hline Bell & 2001 & 20 & 0 & 4 & $4.0^{\mathrm{a}}$ & $\ldots$ \\
\hline Dwight & 2001 & 20 & 1 & 2 & $0.3^{b}$ & $\ldots$ \\
\hline Sturdy & 2001 & 20 & 5 & 6 & $0.1^{\mathrm{b}}$ & $\ldots$ \\
\hline Williams 82 & 2001 & 20 & 6 & 1 & $3.6^{\mathrm{d}}$ & $\begin{array}{l}\cdots \\
\ldots\end{array}$ \\
\hline LN92-12033 & 2001 & 20 & 2 & 4 & $0.7^{\mathrm{b}}$ & $\ldots$ \\
\hline LN92-12054 & 2001 & 20 & 8 & 5 & $0.7^{\mathrm{b}}$ & $\ldots$ \\
\hline Location total & $\ldots$ & 120 & 22 & 22 & $\ldots$ & $1: 1$ \\
\hline Hancock, WI & & & & & & \\
\hline Bell & 1999 & 20 & 0 & 12 & $12.0^{\mathrm{a}}$ & $\ldots$ \\
\hline BSR-101 & 1999 & 20 & 12 & 0 & $12.0^{\mathrm{a}}$ & $\ldots$ \\
\hline Dwight & 1999 & 20 & 0 & 1 & $1.0^{\mathrm{b}}$ & $\ldots$ \\
\hline Sturdy & 1999 & 20 & 13 & 0 & $13.0^{\mathrm{a}}$ & \\
\hline Location total & $\ldots$ & 80 & 25 & 13 & $\ldots$ & $1.9: 1$ \\
\hline Janesville, WI & & & & & & \\
\hline Bell & 2001 & 20 & 0 & 12 & $12.0^{\mathrm{a}}$ & $\ldots$ \\
\hline Dwight & 2001 & 20 & 1 & 2 & $0.3^{\mathrm{b}}$ & $\ldots$ \\
\hline Sturdy & 2001 & 20 & 5 & 9 & $1.1^{\mathrm{b}}$ & $\ldots$ \\
\hline Williams 82 & 2001 & 20 & 8 & 7 & $0.1^{\mathrm{b}}$ & $\ldots$ \\
\hline LN92-12033 & 2001 & 20 & 2 & 10 & 5.3 & $\ldots$ \\
\hline Location total & $\ldots$ & 100 & 16 & 40 & $\ldots$ & $1: 2.5$ \\
\hline Monmouth, IL & & & & & & \\
\hline Bell & 2001 & 20 & 0 & 5 & $5.0^{\mathrm{a}}$ & $\ldots$ \\
\hline Dwight & 2001 & 20 & 1 & 1 & $0.0^{\mathrm{b}}$ & $\ldots$ \\
\hline Sturdy & 2001 & 20 & 6 & 0 & $6.0^{\mathrm{a}}$ & $\ldots$ \\
\hline Williams 82 & 2001 & 20 & 14 & 0 & $14.0^{\mathrm{a}}$ & $\ldots$ \\
\hline LN92-12033 & 2001 & 20 & 0 & 6 & $6.0^{\mathrm{a}}$ & $\ldots$ \\
\hline LN92-12054 & 2001 & 20 & 6 & 0 & $6.0^{\mathrm{a}}$ & $\ldots$ \\
\hline Location total & $\ldots$ & 120 & 27 & 12 & $\ldots$ & $2.2: 1$ \\
\hline Rosemount, MN & & & & & & \\
\hline Bell & 1999 & 30 & 0 & 23 & $23.1^{\mathrm{a}}$ & $\ldots$ \\
\hline BSR-101 & 1999 & 30 & 8 & 4 & $1.3^{\mathrm{b}}$ & $\ldots$ \\
\hline Dwight & 1999 & 30 & 5 & 2 & $1.3^{\mathrm{b}}$ & $\ldots$ \\
\hline Sturdy & 1999 & 30 & 3 & 16 & $8.9^{\mathrm{a}}$ & \\
\hline Location total & $\ldots$ & 120 & 16 & 45 & $\ldots$ & $1: 2.8$ \\
\hline St. Paul, MN & & & & & & \\
\hline Bell & 1999 & 30 & 0 & 16 & $16.0^{\mathrm{a}}$ & $\ldots$ \\
\hline BSR-101 & 1999 & 30 & 0 & 20 & $20.0^{\mathrm{a}}$ & $\ldots$ \\
\hline Dwight & 1999 & 30 & 0 & 2 & $2.0^{\mathrm{c}}$ & $\ldots$ \\
\hline Sturdy & 1999 & 30 & 0 & 14 & $14.0^{\mathrm{a}}$ & \\
\hline Location total & $\ldots$ & 120 & 0 & 52 & $\ldots$ & $0: 1$ \\
\hline Urbana, IL & & & & & & \\
\hline Bell & 2001 & 20 & 0 & 0 & $\mathrm{NA}^{\mathrm{e}}$ & $\ldots$ \\
\hline Dwight & 2001 & 20 & 0 & 0 & NA & $\ldots$ \\
\hline Sturdy & 2001 & 20 & 1 & 0 & $1.0^{\mathrm{b}}$ & $\cdots$ \\
\hline Williams 82 & 2001 & 20 & 3 & 0 & $3.0^{\mathrm{d}}$ & $\ldots$ \\
\hline LN92-12033 & 2001 & 20 & 0 & 0 & NA & $\begin{array}{l}\ldots \\
\ldots\end{array}$ \\
\hline LN92-12054 & 2001 & 20 & 1 & 0 & $1.0^{\mathrm{b}}$ & $\ldots$ \\
\hline Location total & $\ldots$ & 120 & 5 & 0 & $\ldots$ & $1: 0$ \\
\hline Total all locations & $\ldots$ & 1,080 & 151 & 261 & $\ldots$ & $1: 1.7$ \\
\hline
\end{tabular}

a Significantly higher value for one of the two genotypes at $P=0.05$.

${ }^{b}$ NS: frequencies of two genotypes are not significantly different.

${ }^{\mathrm{c}}$ Significantly higher value for one of the two genotypes at $P=0.20$.

d Significantly higher value for one of the two genotypes at $P=0.10$.

${ }^{\mathrm{e}} \mathrm{NA}$ : not applicable. 
Table 2. Number of soybean stems tested of seven different soybean cultivars with a polymerase chain reaction test from three to eight different yearlocations combined for 1999 and 2001, and number of stems that tested positive for genotypes A and B of Phialophora gregata by cultivar

\begin{tabular}{|c|c|c|c|c|c|c|}
\hline Cultivar $^{b}$ & $\begin{array}{l}\text { No. year-locations } \\
\text { per cultivar }\end{array}$ & $\begin{array}{c}\text { Total no. stems } \\
\text { tested }\end{array}$ & $\begin{array}{l}\text { No. stems } \\
\text { infected }\end{array}$ & $\begin{array}{c}\text { Infected with } \\
\text { genotype } \mathbf{A}(\%)\end{array}$ & $\begin{array}{c}\text { Infected with } \\
\text { genotype B (\%) }\end{array}$ & $\begin{array}{c}\text { Ratio of stems } \\
\text { with A:B }\end{array}$ \\
\hline Bell $^{r}$ & 8 & 170 & 87 & 1 & 99 & $1: 99$ \\
\hline BSR-101 ${ }^{r}$ & 3 & 70 & 33 & 73 & 27 & $2.7: 1$ \\
\hline Dwight $^{r}$ & 8 & 170 & 25 & 44 & 56 & $1: 1.3$ \\
\hline Sturdy & 8 & 170 & 94 & 57 & 43 & $1.3: 1$ \\
\hline Williams $82^{\mathrm{s}}$ & 5 & 100 & 51 & 69 & 31 & $2.2: 1$ \\
\hline LN92-12033 ${ }^{r}$ & 5 & 100 & 34 & 15 & 85 & $1: 5.7$ \\
\hline LN92-12054s & 3 & 60 & 22 & 77 & 23 & $3.3: 1$ \\
\hline Grand total & 40 & 840 & 346 & 42 & 58 & $1: 1.4$ \\
\hline
\end{tabular}

${ }^{a}$ Results are presented only for locations where both genotypes A and B were confirmed present.

${ }^{\mathrm{b}}$ Brown stem rot (BSR) resistance: $\mathrm{r}=$ resistant to BSR and $\mathrm{s}=$ susceptible to BSR.

cultivars were predominantly infected by B. Selection for resistance to foliar symptoms of BSR, which are predominantly caused by genotype A, may have resulted in development of resistance to genotype A isolates while leaving the germ plasm vulnerable to $\mathrm{B}$. Alternatively, $P$. gregata may be adapting to resistance and developing genotypes that defeat some of the types of resistance that have been deployed.

The fact that genotypes $\mathrm{A}$ and $\mathrm{B}$ were detected in soybean stems at different frequencies in different geographic locations suggests that the population frequencies of genotypes A and B vary by location. Alternatively, we cannot exclude the possibly that environment affected the pathogen genotype-host interaction. The percentage of plants that were infected by different genotypes of $P$. gregata differed among the nine plot locations in three states using uniform cultivars. These results demonstrate that it is feasible to use a set of soybean cultivars as baiting plants to determine the distribution of $P$. gregata $\mathrm{f}$. sp. sojae. The total percentage of infected plants is an indicator of pathogen density, and the percentages of stems positive for $\mathrm{A}$ and B genotypes are indicators of relative proportions of the two genotypes in that field. Although the percentage of plants that are infected can be influenced by weather conditions such as temperature and moisture, it can be concluded that both genotypes are present at northern Illinois and Wisconsin locations. Data from the Urbana, IL location suggest that genotype $\mathrm{A}$ is the predominant or only genotype there, and either that the pathogen population density is low or the weather conditions were unfavorable for BSR infection because only $4 \%$ of the plants were infected. Data from the St. Paul, MN location suggest that only genotype B occurred there. This conclusion is consistent with the observation that foliar symptoms were not observed for decades at the St. Paul location (J. E. Kurle, unpublished data).

The differences in cultivar preference reported here lead to another significant finding. Not only do the pathotypes or genotypes of $P$. gregata appear to have cultivar preference, but soybean germ plasm sources were identified that can be used to semiselectively bait genotypes A and B from field plots. Use of a uniform set of baiting hosts is important when sampling to ensure that differential selectivity in hosts does not influence the sampling results for the different pathogen genotypes. Based on results from this study, Williams 82 and LN92-12054 can effectively bait genotype A, while Bell and LN92-12033 can effectively bait genotype $B$ across a range of soil types and environments. More generally, locally adapted soybean germ plasms that are infected predominantly by genotype A or B could be used to bait for either genotype of $P$. gregata.

It is important to consider that these results are based completely on detection of the $P$. gregata genotypes by specific PCR amplification of the intergenic spacer sequence of the nuclear ribosomal DNA of the pathogen. Previous studies indicate that this is a reliable and specific method for detecting the presence of and distinguishing between the two pathogen genotypes in soybean tissue, and this amplified marker correlates to other molecular makers and pathogenic traits for $P$. gregata $(6,9)$. The PCR method used to accomplish this work is a valuable tool, without which this type of study would be very difficult. If the PCR method was not available, slow-growing isolates of $P$. gregata would have to be isolated from soybean stems and then inoculated to soybean under appropriate cool environmental conditions, where symptoms would develop over a period of 4 to $6+$ weeks. Thus, although PCR detection has limitations, traditional methods of detection are relatively timeconsuming and laborious.

Much still remains to be discovered about the different genotypes of $P$. gregata. We have an incomplete understanding of the distribution and relative proportion of the two genotypes of $P$. gregata that cause BSR. Plants infected by genotype B of $P$. gregata frequently are unrecognized because of limited development or absence of foliar symptoms. Of equal importance is the relative impact and importance of the two genotypes. Genotype A generally is considered to be the more aggressive and defoliating type, and is thought to cause more damage to yield than genotype $\mathrm{B}$ (19). The importance of genotype B is poorly understood and probably often unrecognized. There is a distinct possibility that, in some host genetic backgrounds or in some environments, genotype B may significantly impact soybean yield and health. In addition, the potential differential interactions that the different genotypes may have with other pathogens, such as soybean cyst nematode, are unknown. Methods are needed to determine the frequency of genotypes A and B of P. gregata and its saprophytic phase in soil to better understand its parasitic phase in soybean plants. Projects have been initiated in the midwestern United States to explore some of these possibilities and to develop answers to basic as well as management issues concerning BSR.

\section{LITERATURE CITED}

1. Adee, E. A., and Grau, C. R. 1997. Population dynamics of Phialophora gregata in soybean residue. Plant Dis. 81:199-203.

2. Adee, E. A., Grau, C. R., and Oplinger, E. S. 1995. Inoculum density of Phialophora gregata related to severity of brown stem rot and yield of soybean in microplot studies. Plant Dis. 79:68-73.

3. Adee, E. A., Oplinger, E. S., and Grau, C. R. 1994. Tillage, rotation sequence, and cultivar influences on brown stem rot soybean yield J. Prod. Agric. 7:341-347.

4. Bachman, M. S., Nickell, C. D., Stephens, P. A., Nickell, A. D., and Gray, L. E. 1997. The effect of Rbs 2 on yield of soybean. Crop Sci. 37:1148-1151.

5. Bachman, M. S., Tamulonis, J. P., Nickell, C. D., and Bent, A F. 2001. Molecular markers linked to brown stem rot resistance genes, Rbs1 and Rbs2, in soybean. Crop Sci. 41:527535.

6. Chen, W. D., Grau, C. R., Adee, E. A., and Meng, X. Q. 2000. A molecular marker identifying subspecific populations of the soybean brown stem rot pathogen, Phialophora gregata. Phytopathology 90:875-883.

7. Chen, W. D., Gray, L. E., and Grau, C. R. 1996. Molecular differentiation of fungi associated with brown stem rot and detection of Phialophora gregata in resistant and susceptible soybean cultivars. Phytopathology 86:1140-1148.

8. Chen, W. D., Gray, L. E., Kurle, J. E., and Grau, C. R. 1999. Specific detection of Phialophora gregata and Plectosporium tabacinum in infected soybean plants using polymerase chain reaction. Mol. Ecol. 8:871-877.

9. Chen, W. D., Shi, X., and Chen, Y. C. 2002. 
Microsatellite markers and clonal genetic structure of the fungal pathogen Phialophora gregata. Mycol. Res. 106:194-202.

10. Chen, Y.-C., Grau, C. R., and Chen, W. 2001. Multiple infection of soybean by the brown stem rot pathogen Phialophora gregata. (Abstr.) Phytopathology 91:S176.

11. Grau, C. R., Oplinger, E. S., Adee, E. A., Hinkens, E. A., and Martinka, M. J. 1994. Planting date and row width effect on severity of brown stem rot and soybean productivity. J. Prod. Agric. 7:347-351.

12. Gray, L. E. 1971. Variation in pathogenicity of Cephalosporium gregatum isolates. Phytopathology 61:1410-1411.

13. Gray, L. E., and Grau, C. R. 1999. Brown stem rot. Pages 28-29 in: Compendium of Soybean Diseases. G. L. Hartman, J. B. Sinclair, and J. C. Rupe, eds. American Phytopathological Society Press, St. Paul, MN

14. Gray, L. E., and Pataky J. K. 1994. Reaction of mung bean plants to infection by isolates of Phialophora gregata. Plant Dis. 78:782-785.

15. Gray, L. E., Peterson, R. E., and Taylor, S. 1985. Gregatin-A - a metabolite produced by Phialophora gregata, the cause of soybean brown stem rot. Phytopathology 75:13121313.

16. Harikrishnan, R., and Yang, X. B.. 1999. Development of soybean brown stem rot in relation to infested residue size, density and depth of placement. Can. J. Plant Sci. 79:469472 .

17. Harrington, T. C., Steimel, J., Workneh, F., and Yang, X. B. 2000. Molecular identification of fungi associated with vascular discoloration of soybean in the north central United States. Plant Dis. 84:83-89.

18. Hughes, T. J. 2001. Role of host genotype and pathogen variability on the development of brown stem rot of soybeans. M.S. thesis, University of Wisconsin-Madison, Madison.
19. Hughes, T. J., Chen, W., and Grau, C. R. 2002. Pathogenic characterization of genotypes A and B of Phialophora gregata $\mathrm{f}$. sp sojae. Plant Dis. 86:729-735.

20. Kurtzweil, N. C., Kinziger, A. E., and Grau, C. R. 2002. Effect of soil pH on symptom development and pathogen reproduction of Phialophora gregata in soybean. (Abstr.) Phytopathology 92:S43.

21. Lewers, K. S., Crane, E. H., Bronson, C. R., Schupp, J. M., Keim, P., and Shoemaker, R. C. 1999. Detection of linked QTL for soybean brown stem rot resistance in 'BSR 101' as expressed in a growth chamber environment. Mol. Breed. 5:33-42.

22. Macguidwin, A. E., Grau, C. R., and Oplinger, E. S. 1995. Impact of planting Bell, a soybean cultivar resistant to Heterodera glycines, in Wisconsin. J. Nematol. 27:78-85.

23. Malvick, D. K. Chen, W., and Grau, C. R. 2002. Genotype distribution and cultivar preference of Phialophora gregata. (Abstr.) Phytopathology 92:S50.

24. Mengistu, A., and Grau, C. R. 1986. Variation in morphological, cultural, and pathological characteristics of Phialophora gregata and Acremonium sp. recovered from soybean in Wisconsin. Plant Dis. 70:1005-1009.

25. Mengistu, A., and Grau, C. R. 1987. Seasonal progress of brown stem rot and its impact on soybean productivity. Phytopathology 77:1521-1529.

26. Mengistu, A., Grau, C. R., and Gritton E. T. 1986. Comparison of soybean genotypes for resistance to and agronomic performance in the presence of brown stem rot. Plant Dis. 70:1095-1098.

27. Mengistu, A., Tachibana, H., Epstein, A. H., Bidne, K. G., and Hatfield. J. D. 1987. Use of leaf temperature to measure thee effect of brown stem rot and soil moistures stress and its relation to yields of soy- beans. Plant Dis. 71:632-634.

28. Nickell, C. D., Bachman, M. S., Stephens, P. A., Nickell, A. D., Cary, T. R., and Thomas, D. J. 1997. Registration of LN92-12033 and LN92-12054 soybean germplasm lines nearisogenic for brown stem rot resistance gene Rbs2. Crop Sci. 37:1987

29. Sills, G. R., Gritton, E. T., and Grau, C. R. 1991. Differential reactions of soybean genotypes to isolates of Phialophora gregata. Plant Dis. 75 687-690.

30. Tachibana, H., and Card, L. C. 1979. Field evaluation of soybeans resistant to brown stem rot. Plant Dis. Rep. 63:1042-1045.

31. Waller, R. S., Nickell, C. D., and Gray, L. E. 1992. Environmental effects on the development of brown stem rot in soybean. Plant Dis. 76:454-457.

32. Whiting, K. R., and Crookston, R. K. 1993. Host specific pathogens do not account for the corn soybean rotation effect. Crop Sci. 33:539-543.

33. Willmot, D. B., Nickell, C. D., and Gray, L. E. 1989. Physiologic specialization of Phialophora gregata on soybean. Plant Dis. 73:290294.

34. Workneh, E., Yang, X. B., and Tylka G. L. 1999. Soybean brown stem rot, Phytophthora sojae, and Heterodera glycines affected by soil texture and tillage relations. Phytopathology 89:844-850.

35. Workneh, F., Tylka, G. L., Yang, X. B., Faghihi, J., and Ferris J. M. 1999. Regional assessment of soybean brown stem rot, Phy tophthora sojae, and Heterodera glycines using area-frame sampling: prevalence and effects of tillage. Phytopathology 89:204-211.

36. Yeater, K. M., Grau, C. R., and Rayburn, A. L. 2002. Flow cytometric analysis of Phialophora gregata isolated from soybean plants resistant and susceptible to brown stem rot. J. Phytopathol. 150:258-262. 